\title{
URSÚA, HISTORIA DE UNA FICCIÓN
}

\author{
Yadira Segura Acevedo \\ (Universidad de Sevilla) \\ yspedagogica@gmail.com
}

\begin{abstract}
RESUMEN: Ursúa es la primera novela del escritor colombiano William Ospina que da inicio a su trilogía del Amazonas, inscrita en el género de la Nueva Novela Histórica. Dentro de este escenario narrativo, el autor construye una mirada distinta del proceso de conquista y colonización del territorio americano, a través de la vida del conquistador navarro Pedro de Ursúa. En esta obra se hipertextualizan relatos polifónicos, protagonizados por personajes históricos y ficticios; hechos que, vistos desde un enfoque semiótico, evidencian la historia y la ficción como realidades sígnicas. En efecto, la hermenéutica literaria se decodificará a partir de la teoría semiótica del filósofo norteamericano Charles Sanders Peirce, con el fin de encontrar una vía de acceso a los diferentes niveles interpretativos del relato literario e historiográfico.
\end{abstract}

PALABRAS CLAVE: Ursúa, historia, ficción, semiótica, reescritura.

\section{URSÚA, HISTORY OF A FICTION}

ABSTRACT: Ursúa is the first novel by the Colombian writer William Ospina that begins his trilogy of the Amazon, inscribed in the genre of the New Historical Novel. Within this narrative scenario, the author constructs a different view of the process of conquest and colonization of the American territory, through the life of the Navarrese conqueror Pedro de Ursúa. In this work polyphonic stories are hypertextualized, starring historical and fictional characters; facts that, seen from a semiotic perspective, show history and fiction as symbolic realities. Indeed, literary hermeneutics will be decoded from the semiotic theory of the North American philosopher Charles Sanders Peirce, in order to find a way to access the different interpretive levels of the literary and historiographic narration.

KEYWORDS: Ursúa, history, fiction, semiotics and rewriting.

El filósofo e historiador estadounidense Hayden White, en su obra El texto histórico como artefacto literario, concibe la historia como la representación de lo real, y la ficción, como la representación de lo imaginable, puesto que «solo podemos conocer lo real contrastándolo o asemejándolo a lo imaginable» (2003: 137). Sobre la base de este pensamiento, las redes sígnicas, definidas ya no solo por simples conexiones de significación, sino por estructuras de resignificación más complejas, reconstruyen en la novela histórica la hipertextualización de los acontecimientos reales. Y es, en este vínculo intertextual, donde William Ospina ${ }^{1}$ reconstruye en su obra narrativa uno de los acontecimientos históricos más trascendentales de la humanidad, el descubrimiento de América, a través de su trilogía del Amazonas (Ursúa, El País de la Canela y La serpiente sin ojos).

${ }^{1}$ William Ospina nació en 1954, en Padua-Tolima. Es considerado uno de los escritores más influyentes de la literatura y el periodismo colombiano en los últimos tiempos. 
La primera novela histórica de esta trilogía, Ursúa, publicada en 2005, entroniza la gesta de conquista y colonización del territorio americano cuyo protagonista es el conquistador navarro Pedro de Ursúa. El autor reescribe el hecho histórico como un referente de inspiración y funda un mundo novelado sobre una reflexión ontológica, epistemológica, semiótica y antropológica del ser americano. De este modo, induce el pensamiento del lector hacia una idea metahistórica a partir de un hecho atroz y heroico que perpetuó «el mayor genocidio de la historia humana» (Todorov, 1998: 14) y protagonizó el redescubrimiento de un gran trozo de tierra, el hallazgo de un río descomunal, de una selva inabarcable y de un mundo innombrable.

Ursúa es un relato histórico y literario que presenta una estructura narrativa no lineal, en continuos flashback y flashforward. En efecto, las historias están entrelazadas o montadas unas encima de otras y van desglosando un contenido sobre la base de mitos y leyendas americanas. El autor relata una circunstancia histórica desde el recuerdo, no construido en la praxis viva - porque él no vivió directamente los hechos-, sino a partir de la lectura de hechos remotos. Indudablemente, la memoria es la que permite conocer el pasado y el presente. A este respecto, Mercedes Juliá, en Las ruinas del pasado. Aproximaciones a la novela histórica posmoderna, afirma que lo que se pretende es conocer la identidad del hombre buscando lo que ya no es; por ello, «la total psicologización de la memoria contemporánea conlleva una nueva economía de la identidad del ser, del funcionamiento de la memoria y de la importancia del pasado» (2006: 57). Y esto es justamente lo que se propone Ospina: explicar lo que no es el hombre americano; no es indio, no es español, no es africano; es mestizo y ve distinto el tiempo y la historia.

Por otra parte, es a través de la semblanza de Pedro de Ursúa como el autor representa a todos los conquistadores que viajaron a América en búsqueda de riqueza y poder: «Ursúa en particular siempre me pareció un personaje complejo, porque hay en él toda la brutalidad que hubo en los conquistadores, todo el salvajismo, toda la codicia, toda la crueldad, pero hubo también todo el valor, el heroísmo, la temeridad, la resistencia física asombrosa» (Ospina, 2018). La selva, el río Amazonas, las tribus colombianas, la tan anhelada ciudad de El Dorado, la india Z'bali o el indio Oramín son otras voces que reconstruye el escritor en esta novela, además de personajes concretamente históricos, como Cristóbal de Aguilar, Inés de Atienza, Miguel Díaz de Armendáriz, Juan de Castellanos, Gonzalo Pizarro, Jorge Robledo, la mariscala María de Carvajal y Mendoza, Hernando Pizarro, Francisco Pizarro, Blasco Núñez de Vela, Pedro de La Gasca, Andrés Hurtado de Mendoza, Pedro de Heredia, Hernán Pérez de Quesada, entre otros.

Así mismo, la guerra es una constante en todo el texto literario; el mismo autor ha afirmado que es un «libro de guerras». Pedro de Ursúa llegó al Perú en 1543 y posteriormente viajó a Cartagena de Indias para encontrarse con su tío Don Miguel Díaz de Armendáriz, Juez de residencia de las Indias. A los diecisiete años recibió el cargo de Teniente Gobernador del Nuevo Reino de Granada. Su primer acto de gobierno fue la violenta destitución del gobernador de Santafé Montalvo de Lugo. Libró varias batallas contra distintas tribus como un guerrero cruel y sanguinario. A los veinticinco años obtuvo la gobernación de Santa Marta y combatió contra los taironas, quienes opusieron gran resistencia. A partir de entonces, tomó un rumbo definitivo: el Perú, animado con las historias de la expedición al país de la canela. 
Desde la Antigüedad clásica, el pensamiento aristotélico distinguía entre historia y poesía: «No corresponde al poeta decir lo que ha sucedido, sino lo que podría suceder, esto es, lo posible según la verosimilitud o la necesidad. En efecto, el historiador y el poeta no se diferencian por decir las cosas en verso o en prosa [...]; la diferencia está en que uno dice lo que ha sucedido, y el otro, lo que podría suceder» (Aristóteles, 1988: 157158). No obstante, White señala que esta distinción «oscurece tanto como aclara ambas nociones. Si hay un elemento de historia en toda poesía, hay también un elemento de poesía en cada relato histórico acerca del mundo» (2003: 136). Ahora bien, el personaje en el contexto novelado no es simplemente un conglomerado de información reflectante, sino que es una fuerza sensible, afectiva, que complementa al sujeto histórico. Modificar la percepción del hecho histórico es, según Ospina, el propósito de la novela histórica, más que ser un reflejo de la historia, porque como cualquier acto creador debe alterar la idea del mundo y la manera de vivir en él:

Hablar de novela histórica es por lo menos hablar de dos aventuras distintas. En el menor de los casos, de un esfuerzo de los escritores por dramatizar con fines de divulgación la información y la documentación que existe sobre un determinado personaje o una determinada época, sin mayores pretensiones literarias o filosóficas. En el mayor, de un esfuerzo de relectura y reelaboración de nuestra idea del pasado, en el que se procura que el lenguaje creador sea el instrumento de esa transformación (2013: 66).

La noción de una conciencia monádica entre realidad y ficción o, aun la idea bidimensional de estos dos estados sobre el suelo de un requerimiento interseccional que los aúna recíprocamente, pero a la vez los distancia, es un presupuesto difícil de esclarecer; puesto que donde estos conceptos se vislumbran andróginos (la historia como lo real, la ficción como lo imaginable), tal razonamiento no termina de encajar. En efecto, en cuanto historiadores, poetas, novelistas y narradores solo se hacen una idea de las cosas en la medida en que las identifican a través de un signo externo que pueden comunicar - un signo que permita una mediación de sus pensamientos con la realidad-, el pensamiento semiótico del científico y filósofo estadounidense Charles Sanders Peirce ofrece una teoría que permite comprender el dúo conceptual historia y ficción desde una dimensión sígnica; máxime cuando dicho semiólogo concibe por primera vez una teoría general de los signos ligada a la epistemología y a la ontología, para demostrar que entre el mundo de las cosas y la inteligencia viva que da cuenta de ellas existe un conjunto de relaciones efectivas donde tienen lugar los signos: entre las mentes con su conciencia y sus representaciones y los objetos referidos (reales o ficticios) sobre los que se realiza alguna experimentación.

En tal sentido, la teoría semiótica de Peirce concibe lo imaginable y lo real como el contenido total de cualquier conciencia, es decir, lo que él denomina «fáneron»: «Propongo emplear el término fáneron como nombre propio para denotar el contenido total de cualquier conciencia (ya que cualquiera es sustancialmente alguna otra), la suma de todo lo que tenemos en la mente, de algún modo cualquiera sin tener en cuenta su valor cognitivo». Esta última expresión: «sin tener en cuenta su valor cognitivo», significa que incluye todo el conocimiento, con independencia de si es real o ilusorio —en lo que aquí atañe, sin tener en cuenta si es histórico o novelado-, y Peirce lo aclara en línea seguida: «Solo señalaré que no limito la referencia a un estado de conciencia instantáneo; puesto que la cláusula "de algún modo cualquiera" incluye la memoria y todo el conocimiento 
habitual» (2004). En otros términos, el «fáneron» es lo que aparece ante la mente, ya sean imágenes reales o ilusorias: «entiendo por fáneron la totalidad colectiva de todo lo que de algún modo o en algún sentido tiene presente la mente, sin considerar en absoluto si se corresponde con algo real o no» (2004).

Sobre esta plataforma teórica — reitero-, los conceptos de historia y ficción siempre se presentan ante la mente. Lo crucial es la relación que establecen con la conciencia del individuo; es decir, como realidades sígnicas. Solo se hace una idea de las cosas reales o no - en este caso de la historia y la ficción- cuando las ideas que conforman las dimensiones de una realidad histórica y de una realidad ficcional surgen a partir de una interacción de la mente y las cosas, y forman parte del proceso evolutivo del mundo en la medida en que son expresiones de hábitos mentales activos. De hecho, la realidad en general, sea dimensionalmente histórica o ficticia, es un signo que representa algo para alguien. Es importante tener presente que la historia y la ficción poseen un registro comunicativo distinto, porque son signos que se inscriben en diferentes planos: uno, el de la historia, surge en la línea del tiempo que lo convierte en pasado (en relato) o en experiencia «tangible»; otro, el de la ficción, surge en el espacio imaginativo sin experiencia palpable y sin límite de tiempo que lo convierte en poiesis.

En la díada historia y ficción, el Objeto - lo que representa el signo- diverge entre lo inmediato y lo dinámico, siempre que un Objeto Inmediato corresponda a la historia o a la idea que directamente transmite el signo y un Objeto Dinámico corresponda a la ficción o a lo que el signo no representa directamente. Peirce aclara:

En cuanto al Objeto, puede denotar el Objeto en cuanto conocido en el Signo y por tanto una idea, o puede ser el Objeto tal como es independientemente de cualquier aspecto particular de sí mismo, el Objeto en aquellas relaciones que solo el estudio ilimitado y final pondrá al descubierto. Al primero lo llamo Objeto Inmediato, al último, Objeto Dinámico (2006).

El Objeto Inmediato es tal como el signo lo representa, es decir, la idea que directamente transmite el signo; mientras que el Objeto Dinámico es la realidad que determina al signo, independientemente de cualquier aspecto particular.

Desde este enfoque semiótico, el mejor instrumento teórico para reelaborar el pasado en la obra literaria de Ospina es el lenguaje (el signo); ese artefacto lingüístico que «lleva a vivir los hechos con mucha más intensidad que la historiografía» (Ospina, 2013: 65). A través de la teoría de Peirce, el lector «inmediatiza»(OI) y dinamiza (OD) Ursúa en su naturaleza sígnica, interpretando los gustos, las creencias y los sentimientos de los personajes. Pero para poder acceder a estas experiencias, es necesario que se dé un proceso de comunicabilidad entre el personaje y el lector; por este motivo, estas tienen que ser objetivadas y transmisibles simbólicamente, es decir, primero deben ser signos. Como en cualquier proceso comunicativo, si no existen parámetros claros de transmisión de información, el signo no existirá y no podrá existir un diálogo entre personajes y lector. No obstante, los diálogos que se establecen a partir de la obra literaria alcanzan grados de complejidad más elevados que los de cualquier otro tipo de comunicación. Evidentemente, no cabe duda de que el escritor y el lector siempre están interpretando signos en un proceso gradual; el lector se relaciona fundamentalmente con dos tipos de signos: la obra literaria en sí misma y su Objeto o lo representado; el escritor, en cambio, ante todo se relaciona con un fragmento del universo a partir del cual inicia la configuración creativa. Así mismo, el autor no solo se relaciona con la realidad objetual que representa en su obra, sino que determina la realidad a través del signo proposicional. 
Y es precisamente como signo cuando la obra trasmite su artisticidad, no meramente informativa en un sentido corriente.

Conviene repetir que la obra literaria es territorio de ficción, una representación simbólica que está en lugar de los sueños y de las posibilidades, tanto como en lugar de realidades pasadas o presentes. Para William Ospina «la novela es el escenario de este mundo despojado de toda tutela trascendental, la novela es la aventura de los individuos en un mundo sin dioses, sometida a un orden de explicaciones completamente humano» (2013: 59). En la literatura, el hombre le da rienda suelta a su imaginación; todos sus deseos y pasiones son posibles: es héroe, maleante, mendigo, jerarca, madre, padre, hombre, niño, dios, demonio, y todo lo que desee, mientras permanezca en la dimensión literaria donde el tiempo, el espacio y las acciones se pueden transformar y prolongar indefinidamente. Mario Vargas Llosa, en su texto La verdad de las mentiras, afirma que las novelas ofrecen unas posibilidades de experiencias o vidas que la vida verdadera niega: «Ese espacio entre nuestra vida real y los deseos y las fantasías que le exigen ser más rica y diversa es el que ocupan las ficciones» (2002: 21).

La realidad que se ve en las novelas se superpone a la propia realidad actual del hombre y la «rectifica», puesto que hace posible la existencia que el hombre quiso inventar para vivir intensamente lo no vivido o, en el caso de la novela histórica, para revivir un pasado que el tiempo hace inalcanzable en cuanto experiencia viva y presente. De manera que el artista y el lector ingresan en la literatura para retomar un rumbo hacia lo desconocido, hacia la realidad ficcional que posibilita infinidad de existencias. Por ello, el autor y el lector, tanto en su actividad creativa como interpretativa, continuamente están viviendo distintas experiencias. Por ejemplo, una de las perspectivas que ofrece el escritor de novela histórica es la expresión de circunstancias emotivas o el relato de esos «pequeños detalles» que pasaría por alto un documento historiográfico, puesto que debido a su condicionamiento objetivo resultarían menos admisibles al proporcionar poca fiabilidad. Y estas circunstancias son las que hacen que «el relato histórico esté vivo» - como lo dice Ospina - o lo amurallan para hacerlo parecer ante el lector más verosímil; no como una simple anécdota o una circunstancia pasajera, sino como una experiencia palpable y verdadera. Entonces, los personajes no se presentan como presencias robóticas, sino como seres que sienten, sufren y se emocionan. Por ejemplo, Leonor Díaz de Armendáriz, madre de Pedro de Ursúa, desde el momento en que vio partir a su hijo supo que era para siempre $\mathrm{y}$, entonces, los pensamientos no dejaron de atormentarla premonitoriamente: «ella no podía ignorar que el muchacho se estaba despidiendo para siempre del viejo solar de los Ursúa, bañado en la sangre generosa de sus abuelos; que su hijo no vería más los rebaños de ovejas por las lomas, y no dormiría nunca más a la sombra de los montes que asediaron sus antepasados de Aquitania» (Ospina, 2005: 30).

De manera similar, Ursúa siente la soledad; ayer, sintiéndose poderoso bajo el escudo protector de su tío Armendáriz y hoy, despoblado, vacío y con la única certeza de saber que la fuerza que lo levantará es la de su propio brazo:

A Ursúa ya no le dolió el desamparo que su tío estaba tratando de sobrellevar con dignidad. Tuvo la nítida sensación de que ahora solo podía contar con su fuerza. Y, como siempre ocurre cuando perdemos las cosas, vislumbró todo lo que había tenido: su soporte en las Indias, el suelo firme que había sido su tío para sostenerse en estas regiones desconocidas, tan lejos de Navarra y de Dios. Pero algo había terminado. Sintió la doble soledad del momento (Ospina, 2005: 342). 
Cabe anotar que los pensamientos de los personajes también hacen parte de esa vibración del ser que los convierte en entes vivos, porque reflejan los recuerdos y registran los deseos. Y esta es una cuota más de esa completitud que hace el escritor del dato histórico para hacerlo más verídico, más artístico y, quizás, más poético: «Lentamente me hice a la idea, pensé en la tumba de mi padre, pensé en tantos guerreros de los que me hablaba en sus cartas mi maestro Oviedo, que ahora eran polvo del Imperio (¡quién me hubiera dicho que por esos días Ursúa en Panamá les daba vuelta a los mismos pensamientos!)» (Ospina, 2005: 445). Los pensamientos y los sentimientos que aparecen reflejados en las novelas históricas son los que permiten silenciar las circunstancias presentes e ingresar al pasado para vivirlo. Si el escritor no abriera esos brotes de «intimidad» del hecho que relata, seguramente pronto el lector lo olvidaría, porque no serían parte de su vida; pero cuando en una novela se ven los hechos en su fibra humana, el receptor los arrastra y se encarna en los personajes para ver y oír con ellos, para sentir su reciedumbre. Evidentemente, el lector no solo accede a estas experiencias sino que parece vivirlas realmente, ocupando, incluso, los espacios de introspección de los personajes: «Solo el no tener mando hace que los delitos de los soldados sean menos atroces, y si mis manos solo están manchadas de la sangre que vertí para defenderme, ello apenas significa que nunca tuve el poder suficiente para ser más malo que los otros» (Ospina, 2005: 358). Se ve, en Cristóbal de Aguilar — personaje que habla en este fragmento-, a un hombre que reconoce el nivel de miseria al que podría haber llegado si le hubieran concedido el poder $y$, al ver la ruindad de su condición humana, el lector se pone en su lugar y, seguramente también como él, se queda un rato meditando.

William Ospina, como otros escritores, encuentra la manera de trasladar la realidad a un escenario de ficción, para ser vivida e interpretada de distintas formas sobre el mismo ideal de lo admirable en sí mismo. Y allí, en ese mundo creado, la realidad se magnifica para dejar fluir un universo de realidades intemporales que se van desplegando cada vez que el lector interpreta la obra literaria. De este modo, el escritor deja en evidencia varios componentes en distintos planos expresivos o instancias discursivas con procesos sígnicos propios. Y una de estas instancias es precisamente el lenguaje que reelabora artísticamente en sus obras. Si de algo no cabe la menor duda es del impresionante caudal poético que surge en cada una de sus novelas; la poesía es el motor creativo de la narrativa ospiniana sobre la cual construye el entramado de leyenda y tragedia de un hecho histórico trascendental.

En la narrativa de Ospina el lenguaje poético es el encargado de crear la ilusión y la ficción; y a través de esta ilusión el escritor conduce la imaginación hacia la vivencia del hecho histórico, no simplemente como la representación de un recuerdo o un acontecimiento pasado, sino quizás como el «redescubrimiento» ${ }^{2}$ de ese pasado para hacerlo realmente visible, más vital, más palpable. Y es justamente en este sentido que Kurt Spang distingue dos tipos de novela histórica: la ilusionista y la antiilusionista:

\footnotetext{
${ }^{2}$ Se utiliza intencionalmente el término «redescubrimiento» propuesto por Elzbieta Slodowska, en su libro La parodia en la nueva novela hispanoamericana. Según esta investigadora, «en los años recientes parece haber incrementado el interés histórico de los novelistas hispanoamericanos por el descubrimiento, la conquista y el periodo colonial de América. Este interés - coadyuvado por las estrategias interpretativas de metadiscursos (post)estructuralistas - ha producido una serie de novelas que podríamos denominar de "redescubrimiento"» (1991: 34). Aunque las novelas de Ospina no tienen la carga paródica de las citadas por Sklodowska, se pueden denominar novelas de redescubrimiento, por su temática y la época en la que fueron creadas.
} 
Al introducir para la tipología de la novela histórica los términos ilusionista y antiilusionista me inspiro en una distinción ya clásica en el ámbito de la dramatología, donde la etiqueta «ilusionista» se refiere al teatro aristotélico en el sentido de un teatro cuyo interés es el de crear la ilusión de realidad y captar la atención del receptor de tal forma que pierda la conciencia de asistir a una representación dejándose implicar, casi hipnotizar, por la problemática de la obra y de las figuras; en cambio, el teatro antiilusionista insiste constantemente en el carácter ficticio del drama y de la representación, intentando «despertar» a los receptores a través de recursos de alienación tal como se observan de forma manifiesta en el teatro de Bertolt Brecht (1998: 65).

Es evidente que la obra de Ospina no pretenden que el lector pierda completamente la conciencia; que la pierda sí, con las descripciones y el lenguaje poético que lo sumergen en un universo arcano, inmensamente impactante; un mundo intangible que solo puede ver a través de la imaginación. Pero otra razón importante que hace bullir el alma estética de esta escritura, que también lleva al lector a un estado de introspección, es el asombro que causa el simple recuento de hechos atroces; la sola enunciación denotativa de estos acontecimientos impacta tanto que, con solo escucharlos, el nivel de conciencia del lector repudia drásticamente esa realidad: «El hambre había llevado a las tropas de Spira a extremos pecadores: cuatro soldados hambrientos hallaron en una aldea un bebé indio descuidado por su madre, y estaban entregados a la tarea impura y clandestina de comer las carnes y el caldo que habían preparado» (Ospina, 2005: 167). Y mientras el lector viaja por ese mundo de atrocidades, de cascadas y tempestades, la voz del narrador súbitamente lo saca del trance y lo conduce a la realidad, al relato despojado de ficción: «Recuerdo la primera vez que intenté contar esta historia. Fue en el Tocuyo, poco después de escapar de la selva y de los ojos viscosos de Aguirre. Quise escribir, para no olvidar nada, todo lo que Ursúa me había contado en un barco por el mar del sur» (Ospina, 2005: 126).

Teniendo en cuenta que Spang ha dicho que «el objetivo es evitar que se produzca en el lector la ilusión de autenticidad y totalidad del contenido presentado, es más, velada o abiertamente el autor trata de "despertar" al lector, de sacarlo de una posible "hipnosis" y llamar su atención sobre el carácter de artefacto del texto que está leyendo» (1998: 70), se puede decir que la narrativa de Ospina se aproxima a las características de la novela antiilusionista. Así mismo, otro recurso utilizado por el autor para lograr un ambiente antiilusionista en su obra son las notas en las que advierte que la historia que narra es verdadera: «Los hechos que se cuentan son reales y casi todos los personajes lo son también» (Ospina, 2005: 473). De este modo, se crea la coincidencia entre historia y ficción o - en palabras de Spang - : «se ignora por tanto, o por lo menos se esconde, el hiato entre los dos ámbitos de la historia y la literatura. No es raro que el autor afirme que la historia que narra es verdadera o aduce otras pruebas que garantizan su veracidad» (1998: 66). Ursúa expresa una visión fidedigna del hecho histórico, pero no se basa en la repetición monótona de un acontecimiento previamente conocido, sino que lo completa y las líneas ilusionista y antiilusionista transitan en un espacio de constantes intersecciones.

Desde otra perspectiva, los conceptos ilusionismo y antiilusionismo propuestos por Spang, corresponden a lo que Fernando Aínsa, citado por Lukasz Grützmacher, en ¿El descubridor descubierto o inventado?, define como novela histórica con «fuerza centrípeta» y novela histórica con fuerza centrífuga:

En su artículo [«La reescritura de la historia en la nueva narrativa latinoamericana»] Aínsa observa dos tendencias opuestas, presentes en las novelas históricas contemporáneas. Por 
un lado, se sitúan los textos que pretenden reconstruir el pasado, por el otro, los que lo deconstruyen. Por un lado, las novelas que se fundamentan en las fuentes historiográficas disponibles, por el otro, las surgidas de la imaginación libre de sus autores. Esta bifurcación de la novela histórica contemporánea corresponde a las dos fuerzas indicadas por Elzbieta Sklodowska en su libro La parodia de la nueva novela hispanoamericana (1991: 29). La fuerza centrípeta dirige el discurso novelesco hacia la construcción de una visión fidedigna y coherente del pasado. De modo que el proceso de reescribir la historia no se limita a cuestionar la visión del pasado transmitida por la historiografía y la literatura europeas, quiere reemplazarla con una descripción de la historia de América hecha desde el punto de vista de los perdedores y de los marginados. La nueva imagen de la historia, que pretende sustituir lo falso por lo verdadero, aspira a convertirse en la base de una identidad independiente de los hispanoamericanos. No obstante, a la fuerza centrípeta se opone la fuerza centrífuga, relacionada con la crisis del concepto de la verdad. Esta fuerza se expresa en la deconstrucción de cada discurso que tenga pretensiones de ser una reconstrucción verdadera del pasado (Aínsa en Grützmacher, 2009: 29).

No obstante, la deconstrucción del discurso «verdadero» del pasado no corresponde precisamente a la fuerza centrífuga de la novela histórica de Ospina, porque en este caso lo que se manifiesta es una construcción más allá de la información que nos arroja el dato histórico, es decir, un afianzamiento de la fuerza centrípeta. Por lo tanto, la fuerza centrífuga no es la demolición de la visión fidedigna del pasado, sino la reconstrucción de este. De todos modos, Ursúa fundamentalmente expresa una visión fidedigna del hecho histórico, pero no se basa en la repetición monótona de un acontecimiento previamente conocido, sino que lo completa con el poder de la fuerza centrífuga; siempre que esta se entienda como la escritura que agrega el autor a partir de su imaginación. Los mitos, por ejemplo, teóricamente no varían, porque no pueden desprenderse - ni en el contexto histórico, ni en el contexto literario- de su dimensión artística ni de sus niveles significativos, pero al contextualizarlos enriquecen su poiesis.

En Ursúa las líneas ilusionista y antiilusionista transitan en un espacio de constantes intersecciones. Se podría argumentar que es una novelas histórica con un cúmulo de fuerzas centrípetas y centrífugas en constante interacción - tal como Susanne Languer lo concibe en la danza-; fuerzas en las que se «elevan» los sentimientos y pensamientos del lector. No es solo el impacto estético del lenguaje lo que «afecta»al sujeto de la recepción; también la fuerza centrípeta que aflora en el relato no imaginado. Y esta interacción de fuerzas es lo que hace consciente al lector del pasado y de la trascendencia de este pasado en el presente, para que pueda comprender lúcidamente la sociedad en la que está inmerso.

Entonces, en Ospina se percibe la reescritura del hecho histórico - ilusionista y antiilusionista - cuando el protagonista, por ejemplo, ya no es el terrible Lope de Aguirre - enigmático personaje que se ve desplazado por la personalidad temeraria y heroica del conquistador navarro - y es Pedro de Ursúa, quien se convierte en la figura central de esta historia, consolidando su preeminencia con las circunstancias trágicas de su prematura muerte que, a fin de cuentas, lo eleva a la categoría de héroe. Y es aquí cuando la historia se subvierte, entronizando ya no al asesino ni al verdugo, sino a la víctima; reconociendo y dignificando a un hombre que, a diferencia de Aguirre, descubrió en América su gran tesoro: el amor de una hermosa mujer; un guerrero incansable que en la gloria de sus triunfos encontró la puerta de entrada al poder; que supo vencer al miedo e, incluso, al dolor; que no le tembló la mano para ayudar o matar; un hombre en el que 
«estaban desde siempre unidos, inseparablemente, el agua y el fuego» (Ospina, 2005: 428).

Partiendo de la premisa de que el presente se construye sobre el pasado, es evidente que la novela de Ospina construye una perspectiva indirecta sobre el presente, con el propósito de aflorar un pensamiento en cierto modo «metahistórico», en cuanto que en la narración de un acontecimiento histórico implícitamente está la revelación de un hecho presente que es a la vez la consecuencia de ese pasado. Ahora bien, en relación con los seis rasgos de la Nueva Novela Histórica — citados por Seymour Menton-, en Ospina destacan unas propiedades más que otras; por ejemplo: la ficcionalización de personajes históricos, la metaficción o los comentarios del narrador sobre el proceso de creación, la intertextualidad y los conceptos bajtinianos de lo dialógico.

La ficcionalización del personaje histórico en William Ospina no es ostensible, porque en general es un calco del retrato histórico. Al escritor le interesa que los lectores sean conscientes de la veracidad de los acontecimientos, pero enriquecidos con hechos imaginados o intensificados por el autor, con la intención de fortalecer la credibilidad del relato:

Yo creo que uno puede leer un libro de historia y no quedar con la sensación de haber vivido unos hechos, pero cuando uno lee una novela, por lo menos mi propósito es que el lector se sienta lo más cerca posible de los hechos: que, si cayó un rayo, el lector sienta que estuvo ahí. Por ejemplo, en Ursúa hay un grupo de hombres que están jugando cartas en la cubierta de un barco, en el puerto del Cabo de la Vela o de Santa Marta y, sin que haya lluvia, ni tormenta, cae un rayo sobre el barco. Eso lo registran los historiadores, lo registran los cronistas, lo registran las cartas de la época; los hermanos de Gonzalo Jiménez de Quesada estaban en ese barco y el fundador de Tunja estaba en ese barco cuando ocurrió ese hecho que está documentado históricamente y que sin embargo parece un hecho fantástico. Ya que yo sé que el hecho ocurrió, mi deber como escritor es darle vivacidad y verosimilitud en el relato. Por eso, en la novela hay cosas que uno no encuentra en el relato historiográfico; por ejemplo, trozos de carta de baraja quemados en la cubierta, fragmentos de cabina rotos por el impacto del rayo y quemados por el fuego del rayo. De manera que es eso; un hecho histórico registrado, escenificado, representado y reconstruido para que el lector sienta la intensidad de ese hecho. Entonces, para mí, es muy importante que los lectores sepan que los hechos ocurrieron, pero también es muy importante que sientan que estuvieron cerca y que los recuerde hasta donde eso sea posible como una experiencia personal (Ospina, 2018).

\section{REESCRITURA Y SEMIOTICIDAD EN URSÚA}

La teoría semiótica de Peirce enuncia que el «fáneron» es el contenido total de cualquier conciencia; por lo que sin «fáneron» no se puede concebir el signo, puesto que solo existe pensamiento en signo en la medida en que este contribuye a la conformación de los hábitos mentales. De este modo, en la epopeya de conquista y colonización del continente americano que reescribe William Ospina en Ursúa, el reconocimiento y aceptación del «otro», del que habla Todorov, demuestra que el contenido de conciencia de españoles e indios no coincidió ni correspondió a un único pensamiento (Interpretante), tanto en unos como en otros; los españoles no comprendieron los signos de la cultura aborigen y los indios, antes del asentamiento europeo, tampoco entendieron el significado de la cultura invasora. En otras palabras, el problema de la conquista de América fue fundamentalmente de comunicación; españoles e indios no comprendieron 
sus signos, porque la relación tripartita entre Representamen, Objeto e Interpretante que constituían sus códigos o lenguajes eran distintas; razón por la cual el contenido de sus conciencias correspondió a dos mundos diferentes. Unos y otros construyeron sus propias redes comunicativas en direcciones distintas: los indios basaron la incomprensión del otro en la negación del Nuevo Mundo, mientras que los españoles basaron la comprensión del otro en la imposición del viejo mundo:

Europa tiene dogmas y linajes y arcángeles: las Indias son otra manera de vivir, de perseguir fortuna, de hablar con la tierra y sus dioses. Aquí la lengua no nombra las mismas cosas ni las mismas pasiones, aquí verdad y mentira parecen tejidas con otra sustancia, aquí todavía al mundo lo gobiernan los sueños, si no las pesadillas; el oro está más lleno de promesas y arrastra más hombres incautos a la muerte; nada logra volverse costumbre, la sorpresa es el hábito, y cada día trae un sabor mezclado de frustración y de milagro (Ospina, 2005: 82).

En este nivel de entendimiento, Todorov ha anunciado que la función de información es esencial, pues «aquellos que no se ocupan de saber, igual que los que se abstienen de informar, son culpables ante su sociedad»(Todorov, 1998: 194). La comunicación de estos dos pueblos, desde un enfoque semiótico, ${ }^{3}$ no encontró eco en ninguna de las dos partes, porque el mundo no estaba designado para el otro; por lo tanto carecía de significación: «Un mundo cuerdo es un mundo en el que hay Otro gracias al cual el mundo de mi gozo llega a ser tema con una significación. Las cosas adquieren una significación racional y no solamente de simple uso, porque Otro está asociado a mis relaciones con ellas» (Levinas, 2002: 222).

La ruptura comunicativa entre españoles e indígenas obedeció a un problema de desarticulación sígnica, de incomprensión de los procedimientos semióticos de estas dos culturas; no fue exclusivamente de índole verbal o lingüística; la ruptura también se creó en el ámbito visual, gestual o simbólico. Son incontables las descripciones en la novela donde la escritura revela la disparidad de palabras y sentimientos. Por ejemplo, el oro era el máximo motivador de la contienda y, en sí mismo, era el Objeto, pero la valoración e interpretación que cada cultura le dio fue distinta; para unos fue riqueza, mientras que para otros fue ofrenda: ${ }^{4}$ «Lo que más extrañaba a los nativos es que los españoles nunca estuvieran satisfechos de ofrendas. Me veo tentado a sonreír con indulgencia al pensar cuán incomprensible era para ellos la avidez por el oro que muestran estos hombres» (Ospina, 2005: 180). La profanación a las creencias más sagradas de los indios fue devastadora. La conciencia mítica y religiosa del oro fue el Interpretante de un signo que solo comprendieron los indios, mientras que en el invasor hubo un obscurecimiento de la cultura ajena; no obstante, el asombro y la perplejidad fueron mutuos; el impacto que causó lo desconocido afectó significativamente a indios y blancos. Se puede ver, entonces, que el Objeto es signo inteligible siempre que se logre objetivar en el pensamiento de otro; si no hay una mirada común, hay una depreciación del Objeto en su significación:

\footnotetext{
3 Todorov afirma que «toda investigación sobre la alteridad es necesariamente semiótica, y recíprocamente: lo semiótico no puede ser pensado fuera de la relación con el otro» (1998: 170).

${ }^{4}$ «Colón no dejaba de alabar la generosidad de los indios que daban todo por nada; le parecía que a veces rayaban en la tontería: ¿por qué aprecian por igual un pedazo de vidrio que una moneda, y dan el mismo valor a las monedas insignificantes que a las de oro?» (Todorov, 1998: 46).
} 
El lenguaje hace posible la objetividad de los objetos y su tematización. Ya Husserl ha afirmado que la objetividad del pensamiento consiste en el hecho de ser válido para todo el mundo. Conocer objetivamente sería, pues, constituir mi pensamiento de tal manera que obtenga ya una referencia al pensamiento de los otros. ${ }^{5}$ Esto que comunico se constituye de antemano en función de los otros. Al hablar no transmito a otro lo que es objetivo para mí: lo objetivo solo llega a ser objetivo por la comunicación (Levinas, 2020: 223).

En Ursúa, William Ospina traslada la realidad a un escenario de ficción, para ser vivida e interpretada de distintas formas sobre el mismo ideal de lo admirable en sí mismo. Y en ese mundo creado la realidad se magnifica para dejar fluir un universo de realidades intemporales que se van desplegando cada vez que el lector interpreta la obra literaria. De este modo, el escritor hace evidente varios componentes en distintos planos expresivos o instancias discursivas con procesos sígnicos propios. Y una de estas instancias es precisamente el lenguaje que reelabora artísticamente en sus obras. Ahora, en el contexto histórico de Pedro de Ursúa, se puede observar que la historiografía muestra al personaje como un signo de un Objeto real o de un individuo de carne y hueso que nació, vivió y murió como conquistador español. Entonces, este hombre de carne y hueso es el Objeto Inmediato de este primer signo y el Pedro de Ursúa de la trilogía novelada es otro signo que representa a un personaje literario creado por el escritor; por lo que el Ursúa literario corresponderá a otro tipo de Objeto, el Dinámico, distinto del primer signo. Evidentemente, antes de interpretar este último signo literario, el lector acudirá al personaje no novelado para poder interpretar al Ursúa ficcional. En este sentido, se puede inferir que el segundo Objeto - el de la novela - requiere un nivel interpretativo con un grado de complejidad más avanzado que el del primer Objeto —el de la historia —. En el signo ficcional la significación es compleja, porque al ser connotativa necesita acceder al sistema lingüístico de la lengua natural no novelada aún, para poder decodificar lo que Yuri M. Lotman denomina «sistema de modelización secundaria» ${ }^{6}$ que, en este caso, es el lenguaje literario de las novelas de Ospina. En otros términos, mientras el relato histórico que narra la vida del conquistador navarro Pedro de Ursúa necesita de una decodificación relativamente simple, el relato literario de este mismo personaje necesita de una doble decodificación de la que deriva la complejidad del lenguaje literario o sistema de modelización secundario en la que se expresa su polifonía textual:

El discurso poético representa una estructura de gran complejidad. Aparece como considerablemente más complicado respecto a la lengua natural. Y si el volumen de información contenido en el discurso poético (en verso o en prosa, en este caso no tiene importancia) y en el discurso usual fuese idéntico, el discurso poético perdería el derecho a existir y, sin lugar a dudas, desaparecería. Pero la cuestión se plantea de un modo muy diferente: la complicada estructura artística, creada con los materiales de la lengua, permite transmitir un volumen de información completamente inaccesible para su

${ }^{5}$ «El preguntar por el sentido de la existencia es, por consiguiente, un preguntar con los otros, un co-preguntar. Como tal, este preguntar singular supone el reconocimiento del otro como ser portador de sentido y como ser dialogante, digno de ser escuchado. Por ello, tal preguntar reviste de entrada una dimensión ética y moral: cuando la relación co-preguntar cesa, el sentido se torna en palabra inerte, legitimadora de violencia» (Gómez-Muller, 1997: 39).

${ }^{6}$ El semiólogo ruso Yuri M. Lotman, en su obra Estructura del texto artístico, afirma: «los lenguajes secundarios de comunicación (sistemas de modelización secundaria), es decir, estructuras de comunicación que se superponen sobre el nivel lingüístico natural (mito, religión). El arte es un sistema de modelización secundario. No se debe entender "secundario con respecto a la lengua" únicamente, sino "que se sirve de la lengua natural como material”» (1988: 20). 
transmisión mediante una estructura elemental propiamente lingüística (Lotman, 1988: 21).

Lo que se trata de dilucidar es la diferencia entre historia y ficción desde una perspectiva semiótica en la que el Objeto representado es el mayor rasgo distintivo: en uno, Inmediato y, en otro, Dinámico; así mismo, se dispone de un nivel de complejidad mayor en el signo literario, porque aunque los dos discursos —el histórico y el literariotextualizan al mismo personaje, sus Objetos son distintos. A partir de este marco conceptual, se considera que el volumen de información contenido en Ursúa, aunque parezca ser la reiteración casi literal del discurso histórico, es más extenso y compacto, porque su naturaleza novelada lo convierte en un caudal ilimitado. No obstante, no ocurre esto en el archivo histórico, porque los acontecimientos están circunscritos a un término: empiezan y terminan. Por ello, el Objeto Dinámico de la ficción — dada la condición artística del lenguaje literario - corresponde a un abanico de posibilidades interpretativas; mientras que el Objeto Inmediato del dato histórico se limita a una versión generalizada del hecho narrado, es decir, hace evidente en el signo un aspecto particular del Objeto.

Conviene aclarar que los grados de complejidad y los niveles de lenguaje no son exclusividad de un texto ni de otro y, en ciertas ocasiones, se hacen más o menos ostensibles. Lo que se pretende explicar es que hay relatos históricos en los que también existe la poesía, el arte, la ficción y la imaginación; las crónicas de Indias, por ejemplo, están llenas de metáforas y de figuras musicales que trascienden la mirada objetiva. Hayden White, en Texto histórico como artefacto literario - citando a Northrop Fryeseñala que «cuando el esquema de un historiador llega a un cierto punto de amplitud, se vuelve mítico en forma, y entonces se acerca a lo poético en su estructura» (2003: 110).

Por otra parte, la tendencia a creer que la lengua literaria de la novela histórica es más prolífica en fabulación e imaginación, no impide al lector que a través de la novela él vea el mundo tal como es (Objeto Inmediato), ${ }^{7}$ pues hay un fuerte vínculo que la conecta a ese mundo aún no mitificado. Y es en la representación de ese Objeto Inmediato cuando la obra crea su naturaleza literaria en la que se reafirma el hecho no novelado, quizás en una especie de encumbramiento de la realidad que representa. A este respecto, el escritor William Ospina dio la siguiente respuesta al contestar a la pregunta: ¿Si la historia narrada en Ursúa, como un hecho histórico en sí misma, es un relato novelado, cómo se puede percibir lo verdaderamente ficcional al releer este relato en el contexto literario?:

Yo me propuse, al comienzo, que todo lo que contara fueran hechos que ocurrieron realmente. Lo que me parecía interesante de esta historia era precisamente que el lector pudiera darse cuenta de que estos hechos habían ocurrido; que a veces parecen asombrosos, a veces parecen irreales, a veces parecen fantásticos, pero ocurrieron; ocurrieron realmente, solo que ni la literatura, ni la historia, ni la historiografía lograrán darnos plenamente la nitidez y el detalle de todo lo que ocurrió. Hay muchas cosas a las que solo podemos acceder a través de una suerte de recreación en la ficción, pero para mí es muy importante respetar los hechos y solo allí donde es posible tratar de no inventar,

${ }^{7}$ Alfonso Reyes, en su obra El deslinde, afirma: «La vitalización que adquiere la historia en la presentación literaria es tan intensa, que aún logra predominar sobre anacronismos, errores y caprichos. La literatura de asunto histórico puede acertar con una verdad humana más profunda que los inventarios y calendarios históricos [...]. Y este es el momento de recordar la tesis aristotélica respecto a la primacía filosófica de la literatura sobre la historia $(\mathrm{V}, 17)$. Parece, pues, que de modo general es la historia quien sale ganando en este tipo de fertilización» (1944: 92). 
pero sí deducir unas circunstancias y unos detalles. Eso me parece importante. Muy pronto comprendí que mi propósito de no inventar nada era muy difícil de cumplir, porque si uno quiere que el relato esté vivo, uno tiene que llenarlo de detalles circunstanciales que por lo general los historiadores no registran. Por ejemplo, el historiador no se detiene a decirle a uno si el caballo relinchó o no relinchó o si lloviznó esa tarde cuando iban cabalgando entre Tunja y Santa Fe; pero para el novelista si el caballo no relincha es como si no existiera, si la lluvia no cae, a veces uno no acaba de sentir que está de verdad en el paisaje. Entonces, esos pequeños detalles que el historiador no registra, sin embargo, son tan comunes y son tan necesarios y son tan reales que añadírselos a la historia no le quita nada a la sustancia de los hechos, en cambio sí le añade verosimilitud y vivacidad. Finalmente, ocurre un hecho curioso y es que los lectores terminan creyendo más en esos pequeños detalles que uno añade, porque son parte de su experiencia personal y de la experiencia de todo el mundo; y eso hace que la novela sea un relato de hechos históricos documentados y no un relato de hechos físicos vividos por todos que le dan un sabor mayor de realidad y de cercanía a todo lo que se cuenta (2018).

De manera que lo inmediatamente objetual se convierte en ficción; la historia - que mira directamente al mundo exterior- en ciertas ocasiones da rienda suelta a la ostensible realidad que narra llevándola hasta el umbral de la poiesis. Por lo tanto, lo no histórico se convierte en realidad no literaria para ser un relato que habita en el tiempo, y lo no ficcional se convierte en fabulación para ser un relato que habita en el arte:

De hecho, la historia —el mundo real tal como evoluciona en el tiempo- cobra sentido de la misma manera en que el poeta o el novelista tratan de darle sentido, es decir, dotando a lo que originalmente parece ser problemático y misterioso del aspecto de una forma reconocible porque es familiar. No importa si el mundo es concebido como real o solamente imaginado; la manera de darle sentido es la misma (White, 2003: 38).

Se ha retrasado intencionalmente el concepto de Interpretante, porque es el elemento de la triada (Representamen, Objeto e Interpretante) que va a permitir un discernimiento adecuado entre historia y ficción. Según Peirce, el signo se refiere a un Objeto en la mente del intérprete y la idea que crea es el Interpretante. Esta idea se presenta en forma de signo; por lo tanto, el Interpretante se convierte en otro signo a partir del cual se representa otro Objeto, creándose un nuevo Interpretante, y así sucesivamente: «Un signo está por algo para la idea que produce o modifica. $\mathrm{O}$ es un vehículo que transporta adentro de la mente algo desde afuera. Aquello por lo que está se llama su objeto; aquello que transporta, su significado; y la idea a la que da lugar su interpretante» (Peirce, 2001). Aplicando esta teoría a las novelas de Ospina, por ejemplo, al mencionar el nombre del protagonista Pedro de Ursúa se está reconociendo un signo y, por lo tanto, un Representamen que está en lugar de un Objeto que, en este caso, corresponde al personaje literario creado por el escritor. El Interpretante es, entonces, la imagen o idea que el lector crea en su mente al escuchar el nombre Pedro de Ursúa, y esta idea se convierte en otro signo; sin embargo, aunque cada lector tiene su propia imagen del protagonista, hay una idea previa común - la imagen de un conquistador español valiente, pero a la vez tiránico-, y tal imagen es el Interpretante del Representamen o signo inicial.

Dicho lo anterior, no sobra explicar que el Interpretante se representa en los lectores de distinta manera, pues cada uno crea su propio pensamiento aunque el Objeto sea el mismo para todos. Las percepciones divergen de un sujeto a otro y pueden imaginarlo como un héroe o como un antihéroe, como un tirano o como un hombre valiente y apasionado, etc. En el caso de Ursúa, los Interpretantes están determinados 
por el mismo signo y representan al mismo Objeto, que es el personaje literario (Ursúa). Pero si el Representamen se interpreta exclusivamente desde una perspectiva histórica, la relación triádica cambia generando otro Objeto y otro Interpretante distintos, construidos sobre la base del personaje histórico. Sin embargo, las cualidades de valentía y crueldad están presentes en los dos (el histórico y el literario), porque son rasgos distintivos fundamentales en ambas circunstancias (la real y la imaginada). En efecto, el Ursúa literario no es el mismo Ursúa histórico, porque los dos pertenecen a dimensiones temporales y espaciales diferentes, pero el Interpretante literario siempre va a estar determinado por el Interpretante histórico, puesto que el relato novelado no se puede concebir en ausencia del relato real. El Interpretante no ficcional, en cambio, está determinado por un hecho que aún no es relato, sino circunstancia, experiencia viva.

Pues bien, el interés que suscita explicar los conceptos de historia y ficción desde un enfoque semiótico no es más que el de ser conscientes de que los dos son igualmente signos de la realidad; por lo tanto, ni el ficticio es menos real que el histórico, ni el histórico menos irreal que el novelado. Los dos existen en la mente de los sujetos que los crean y los recrean; solo que uno está más próximo a la inmediatez y el otro, al dinamismo. Desde luego, corresponde señalar que estas aclaraciones orientadas a partir de la semiótica no son una ocurrencia, pues ya antes se había hecho referencia a «la narrativa histórica» — que no es la novela histórica, sino la historiografía-, como representación icónica:

Por supuesto, asumo aquí las distinciones entre signo, símbolo e icono que C. S. Peirce desarrolló en su filosofía del lenguaje. Creo que esas distinciones nos ayudarán a comprender lo que es ficticio en toda representación supuestamente realista del mundo y lo que es realista en todas las manifestaciones ficticias. Nos ayudan, en suma, a responder a la pregunta: ¿de qué son representaciones las representaciones históricas? [...] considerada como un sistema de signos, la narrativa histórica apunta simultáneamente en dos direcciones: hacia los acontecimientos descritos en la narrativa y hacia el tipo de relato o mythos que el historiador ha elegido icono de la estructura de los acontecimientos (White, 2003: 120-121).

Se agregaría a esta disertación el carácter simbólico del relato novelado e historiográfico, en la medida en que son comprensibles a partir de lineamientos convencionales que los determinan como textos ficcionales o como textos históricos; es decir, existen leyes sociales que hacen de estos relatos dimensiones discursivas distintas. Por lo tanto, para que haya narrativa y novela histórica tiene que haber un acuerdo en el que coincidan las significaciones e interpretaciones o ciertos hábitos de creencia mediante los que se establecen asociaciones que permitan imaginar o referirse a algo. Peirce, en su artículo «¿Qué es el signo?» (1999), afirma que los símbolos se hacen a través de pensamientos que implican conceptos, pues no puede haber pensamiento si no existen estas asociaciones. Por lo tanto, es en la comunicabilidad donde se pueden comprender los conceptos de historia y ficción. De manera que un arsenal de información va difundiéndose y reactivándose en el pensamiento que continuamente crece, $\mathrm{y}$ son estos mensajes simbólicos los que marcan la diferencia entre las dimensiones de realidad; hábitos que hacen creer que quizás la ficción es menos real que la historia o que la historia es la negación de la fábula o la adición documental del dato, porque las dos son representaciones mentales que corresponden a determinados hábitos de creencia. Se deduce, entonces, que la historia es el pasado que habita en el presente y que la novela histórica es la prolongación y reactivación de ese pasado para no verlo solamente desde la distancia, sino para convertirlo nuevamente en experiencia. 
En esta misma línea de entendimiento, al hacer referencia a la semiosis del cuerpo y de la voz, conviene destacar que uno de los rasgos más significativos de la raza indígena fue su saber desde el silencio; actitud que Ospina calca y anota en su novela. Pero el silencio del indio no es solo el silencio de la palabra; ${ }^{8}$ también es el silencio del cuerpo, porque hasta el olor, como lo dice el escritor, hace ruido y habla. Los indios eran maestros en el arte del sigilo y en el aquietamiento del ruido; daba la impresión de que sus cuerpos lo absorbían cuando se sentían en peligro y querían ser invisibles: «[El capitán Alfínger] con la mitad de su tropa cruzó, por días largos y tristes, los páramos silenciosos con su vegetación a ras del suelo, donde ni siquiera por eso es posible saber si no hay indios ocultos, ya que en todo el territorio uno puede pasar entre pueblos enteros sin advertirlos [...] y solo cuando quieren pueden ser percibidos» (Ospina, 2005: 314). El silencio de los indios no solo fue un estado de su conciencia; también surgió por el temor que produjo la sujeción y el avasallamiento del opresor: «-“Es bien extraño", suspiró su tío, "porque es evidente la dulcedumbre con que los indígenas aceptan nuestro gobierno, o el silencio con que se someten a lo que no pueden evitar"» (Ospina, 2005: 271).

Se sabe que la comunicación entre estos dos pueblos se dio cara a cara; por ello, su kinésica y proxémica ${ }^{9}$ fueron otras formas sígnicas que también desaprovecharon. $\mathrm{Al}$ no entender su lengua natural, tanto indios como españoles, utilizaron lenguajes no verbales para comunicarse: la actitud de sus manos, los vestigios de sus miradas, la enunciación de sus cuerpos...; todo decía, todo hablaba, todo se codificaba en un universo pluritextual. Los conquistadores pertenecían a la lingüística, a la escritura, a la expresión verbal; mientras que los indígenas obedecían más al lenguaje de sus cuerpos, a la kinésica; más a la oralidad que a la escritura, más al silencio contemplativo que a la palabra, más al gesto indescifrable.

Otro aspecto importante, que causa la invasión y el desalojo obligado en cualquier episodio de conquista, es la «territorialidad». ${ }^{10}$ Acerca de este concepto, Mark Knapp dice lo siguiente: "También es frecuente el término territorialidad en el estudio de la proxémica para designar la tendencia humana a marcar el territorio personal - o espacio intocable - al modo en que lo hacen los animales salvajes o las aves» (1982: 25). En tiempos coloniales, arrasar y matar fue un procedimiento acordado para posesionarse de lo ajeno, y la sangre de los muertos pintó esa línea virtual de territorialidad que una vez trazada era casi imposible de borrar: «La mayor parte de los científicos de la conducta están de acuerdo en que también en el comportamiento humano se da el fenómeno de la territorialidad, lo que ayuda a regular la interacción social, pero que también puede ser fuente de conflicto social» (Knapp, 1982: 114). Pero esa línea divisoria pudo ser trazada tanto por héroes que libraron batallas con honor y valor, como por canallas que no tuvieron otro recurso distinto a la traición para derrotar al enemigo. ${ }^{11}$ Pero, dado que la protección de la fracción de tierra en la que se habita es una de las primeras manifestaciones de territorialidad, las comunidades guerreras - los muzos, por ejemplo- defendieron su suelo con temeridad y no admitieron proximidades distintas a

\footnotetext{
${ }^{8}$ Dice Alfredo Gómez-Muller que «el otro es, en efecto, portador de sentido: cada palabra, cada silencio, cada comportamiento y cada actitud indica una perspectiva de sentido» (1997: 38).

${ }^{9}$ «En general, se entiende por proxémica el estudio del uso y percepción del espacio social y personal» (Knapp, 1982: 25).

${ }^{10}$ En relación con las intrusiones territoriales, Knapp (1982: 115) señala que Lyman y Scott reconocen tres tipos: violación, invasión y contaminación. La que aquí nos interesa es la invasión: «En este caso se trata de un intento de apoderarse del territorio ajeno».

11 «Ursúa, una vez logró dominar con las peores artimañas al pueblo de los muzos, creó el ritual de fundación de la ciudad de Tudela» (Ospina, 2005: 361).
} 
la suya. Fue así como frente al extravagante ritual de fundación de Tudela que protagonizó Ursúa, los muzos, poseídos de venganza, regresaron para no dejar ni una huella de su ciudad en manos ajenas $y$, antes de perderla, prefirieron que se desvaneciera en el viento: «Una nube muy densa cubrió las tierras hasta los cerros tajados de Tena y de Fura, y la venganza de los muzos se cumplió» (Ospina, 2005: 361). La ciudad de las esmeraldas quedó reducida a cenizas. Pero no solo la guerra y la invasión marcaron las relaciones proxémicas; los rangos jerárquicos y las clases sociales también establecieron signos de distancias para proteger y salvaguardar su espacio de poder. El conquistador dispuso de líneas y distancias divisorias para sentirse superior, exigiendo al indígena no sobrepasar este espacio. La proximidad física entre españoles e indios era mínima; no obstante, jerárquicamente estaban muy distantes.

De manera puntual, se deduce que aunque existieron muchos pueblos indios —unos más bravos que otros-, sus movimientos, sus gestos, sus modales... comunicaban sígnicamente o expresaban su modo de ser, y una de las pautas de conducta más comunes entre ellos fue su quietud y serenidad; incluso, cuando los guerreros más valerosos avanzaban - ya fuese para atacar o escapar - lo hacían tan rápido que casi desaparecían. Los indios silenciaron sus voces para oír el río y la selva; cerraron los ojos para ver el relámpago y el arcoíris; entonaron sus rezos para escuchar el canto del sol y la luna; y todo brotó del silencio: «Tantos siglos a la orilla del río volvieron a los hombres diestros para nadar como peces y frenéticos para atacar como caimanes; la familiaridad de los montes los volvió silenciosos como niebla» (Ospina, 2005: 88). El ruido dictador del invasor no les permitió a los indígenas oír a los españoles, ni a estos oír "el silencio" de los indios; no obstante, el ruido y el silencio cohabitaron en un solo espacio y hubo hombres que sí aprendieron a oírse; «maestros» prudentes que lograron callar sus conciencias en estado de «epojé» (Husserl) para «desaber» lo aprendido y comprender el saber ajeno. Uno de ellos fue Juan de Castellanos — cronista y personaje de Ursúa - que, a diferencia de otros cronistas y poetas, no pretendió «agradar la sensibilidad de los lectores de la península, escasos y refinados, transmitiéndoles de un modo fabuloso lo que querían pensar del remoto mundo americano, no lo que este tenía de distinto y perturbador» (Ospina, 1999: 18), sino que procuró describir América a partir de sus propias experiencias. Fue un poeta que convivió con la selva inmensa y sus habitantes; pudo ver con sus propios ojos ese mundo majestuoso y sintió el frío y el calor, el dolor y el placer que produce el contacto con un tiempo y un aire distintos al europeo; por eso, no necesitó inventar nada, porque todo lo vio nacer en América; solo le bastó silenciarse. Fue así - dice Ospina - como Castellanos creó el primer poema verdaderamente americano de la historia escrito en lengua castellana y nombró a este continente por primera vez:

mucho más que una crónica en verso y mucho más que un relato histórico, [fue] un esfuerzo desmedido y afortunado por aprehender a América en el lenguaje y nombrarla por primera vez, no con el tono seco de un informe oficial, ni con el lenguaje fantasioso de un cazador de endriagos, ni con el tono probo pero incoloro de un acumulador de datos, sino con la voluntad de introducir todos esos hechos en el ritmo nuevo de la lengua, en la fluidez de una música, en un orden de belleza y de verdad (Ospina, 1999: 64-65).

En la cultura indígena igualmente hubo indios lúcidos que alcanzaron a oír, ya no el río, sino el avanzar de un ejército que bajaba a América cantando sus himnos sagrados; indios que lograron ver, ya no la selva, sino un mural de piedras y calles tejidas, amarrando ciudades blanquísimas y templos que inclinaban sus torres. Catalina de Zamba 
fue uno de estos indios; una mujer que, siendo india, revistió su cuerpo de finos modales de dama española sin dejar de ser lo que era: la hija silenciosa de la selva y del río. El silencio, agrega Todorov, era un componente fundamental en la educación familiar y el aprender a hablar bien de los indios.

Por otra parte, más allá de expresión kinésica y proxémica, la textualización verbal de la significación es una de las formas de comunicación del individuo más complejas en cuanto a su estructura y a la dimensión articulada de la realidad. Y esta verbalización - que puede ser a nivel oral o escrito - representada en el signo lingüístico, está indisociablemente unida a la sociabilidad del ser, es decir, a sus costumbres, a sus artes, a su moral, a su economía, a su política, a sus saberes: «si uno no conoce a fondo la lengua no puede comprender la cultura» (Todorov, 1998: 213). La lengua de los indios no podía desprenderse de la selva, ni del río, ni del sol, porque estas eran las letras de su alfabeto, su gramática y su semántica; la herencia ancestral a partir de la cual tenía significado su existencia. Y el mundo que se veía a través de una lengua como la omagua no era el mismo mundo que veían los conquistadores. Para los recién llegados el mundo hallado no solo fue indecible, sino además inmencionable. No pudieron nombrarlo, porque no lo conocían. La imaginación de los conquistadores se llenó de imágenes preconcebidas: «Veremos cómo los primeros viajeros que llegaron al continente americano creyeron ver sirenas, cíclopes, panotis y lestrigones, es decir, aquellos monstruos típicos de los relatos de viajes medievales que les eran familiares» (Ramírez, 2001: 46). Colón quiso nombrar ese «mundo nuevo» cambiando todo de nombre; fingió conocerlo y lo desnombró, porque sabía que al darles nombres a las cosas las poseería: «Colón, entonces, sabe perfectamente que esas islas ya tienen nombres, naturales en cierta forma (pero en otra acepción del término); sin embargo, las palabras de los demás le interesan poco ${ }^{12}$ y quiere volver a nombrar los lugares en función del sitio que ocupan en su descubrimiento, darles nombres justos» (Todorov, 1998: 35). Pero esta presuntuosa posesión también lo fue de las personas y se dio nombres a los indios para sustentar su posesión sobre ellos: «Ni siquiera los indios escapan a la marejada de nombres: los primeros hombres que se lleva de vuelta a España reciben los nuevos nombres de don Juan de Castilla y don Fernando de Aragón» (Todorov, 1998: 36).

Para aprender el lenguaje de América había que nacer o renacer allí y empezar de nuevo, pronunciando cada letra y cada palabra en correlación con la naturaleza: «El concepto sería más productivo si se entendiera de modo que incluyera, al lado de la interacción de individuo a individuo, la que tiene lugar entre la persona y su grupo social, la persona y el mundo natural, la persona y el universo religioso» (Todorov, 1998: 75). Si no existía un vínculo con la naturaleza, la lengua por más que se pronunciara era una lengua vacía, porque la palabra más que un discurso era un rito. ${ }^{13}$ A este respecto, Olaya Sanfuentes, en su obra Develando el Nuevo Mundo. Imágenes de un proceso, argumenta que existe «la necesidad de crear un lenguaje, nomenclaturas e imágenes nuevas cuando debemos describir a otro lo que nunca ha visto» (2009: 204). En otros términos, en la conquista de América había tantas palabras nuevas para nombrar que los españoles prefirieron asociarlas a las imágenes que llevaban en sus pensamientos y el Objeto que observaban no era un descubrimiento ni una primicia, porque ya existía en ellos como

12 «Aun en los casos en que no se trata de esclavitud, el comportamiento de Colón implica que no reconoce que los indios tienen derecho a una voluntad propia, que los juzga, en suma, como objetos vivientes [...] la idea de preguntarles cuál es su opinión le es totalmente ajena» (Todorov, 1998: 56).

13 Todorov señala: «la palabra privilegiada entre los aztecas es la palabra ritual, es decir, reglamentada en sus formas y en sus funciones, palabra memorizada y, por lo tanto, siempre citada» (1998: 87-88). 
Representamen e Interpretante asociados a dicho Objeto en una relación triádica: «lo que realmente se representa no es el objeto material situado frente al sujeto, sino una confrontación entre dicho objeto y la definición cultural del mismo que posee el sujeto productor de la imagen» (Ramírez, 2001: 47). En efecto: «A falta de palabras para nombrar cosas nuevas y hasta entonces desconocidas - extrañas a la cultura española-, los cronistas llamaron más de una vez "mezquitas" a los templos indígenas» (Amodio, 1993: 118).

En definitiva, la nueva lengua fue indescifrable y la complejidad de sus sonidos empañó el entendimiento de los visitantes que, antes de aprender el lenguaje de la tribu, prefirieron atribuir otro Representamen a Objetos que ya tenían su propia denominación. El Objeto recreó un Representamen nuevo que no correspondió al signo inicial por el que estuvo dicho Objeto. De este modo, el mundo nuevo oscureció ante la ceguera de los conquistadores y su percepción no tuvo capacidad para abarcarlo y prefirieron ver otro mundo, el imaginado, o se acostumbraron a vivir junto a un agolpamiento de signos que no llegaron a mencionar jamás.

\section{OBRAS CITADAS}

Amodio, Emanuele (1993), Formas de la alteridad: Construcción y difusión de la imagen del indio americano en Europa durante el primer siglo de la conquista de América, Quito, Abya-Yala.

Aristóteles (1988), Poética de Aristóteles, ed. trilingüe de Valentín García Yebra, Madrid, Gredos.

Gómez-Muller, Alfredo (1997), Alteridad y ética desde el descubrimiento de América, Madrid, Akal.

Grützmacher, Łukasz (2009), ¿El descubridor descubierto o inventado? Cristóbal Colón como protagonista en la novela histórica hispanoamericana y española de los últimos 25 años del siglo $X X$, Varsovia, Biblioteka Iberyjska.

Husserl, Edmund (1982), La idea de la fenomenología, Madrid, Fondo de Cultura Económica.

Juliá, Mercedes (2006), Las ruinas del pasado. Aproximaciones a la novela histórica posmoderna, Madrid, Ediciones de la Torre.

Knapp, Mark L. (1982), La comunicación no verbal. El cuerpo y el entorno, Barcelona, Paidós.

Levinas, Emmanuel (2002), Totalidad e infinito. Ensayo sobre la exterioridad, Salamanca, Ediciones Sígueme.

Lotman, Yuri M. (1988), Estructura del texto artístico, Madrid, Istmo.

Ospina, William (1999), Las auroras de sangre, Santa Fe de Bogotá, Ed. Norma.

Ospina, William (2005), Ursúa, Bogotá, Alfaguara.

Ospina, William (2013), La escuela de la noche, Bogotá, Mondadori.

Ospina, William (febrero 2018), Entrevista a William Ospina, «No me hablen oscuramente de las cosas claras, háblenme claramente de las cosas oscuras», en Revista Matices, 78, por Yadira Segura Acevedo, $\quad \underline{\text { http://revistamatices.com.mx/wp- }}$ content/uploads/2018/03/Maticesfebw.pdf $>$.

Peirce, Charles Sanders (1999), «¿Qué es un signo?», <https://www.unav.es/gep/Signo.html>.

Peirce, Charles Sanders (2001), «"Interpretant"/“Interpretante”. "Interpreter"/“Intérprete". "Receiver"/"Receptor"», < $<$ http://www.centro-de-semiotica.com.ar/PeirceInterpr.html >.

Peirce, Charles Sanders (2002), «Fáneron y faneroscopia», trad. incompleta de Juan Magariños de Morentin, parágrafo 1.284. Otra fuente: CP, «The phaneron», 141-42, $<$ http://www.centro-de-semiotica.com.ar/Faneron.html $>$. 


\section{Yadira Segura Acevedo}

Peirce, Charles Sanders (2004), «La base del pragmaticismo en la faneroscopia», trad. de Sandra Ollo. Otra fuente: $\quad C P$ 1.317-21, 4.235-63. $<$ http://www.unav.es/gep/PragmaticismoFaneroscopia.html $>$.

Peirce, Charles Sanders (2006) [29 de febrero de 1909], «Carta a William James», extracto, trad. de Ignacio Redondo. Fuente textual en EP 2:492-97, $<$ http://www.unav.es/gep/James29.02.09Espanol.html $>$.

Ramírez Alvarado, María del Mar (2001), Construir una imagen. Visión europea del indígena americano, Sevilla, Colección América.

Reyes, Alfonso (1944), El deslinde, México DF., Fondo de Cultura Económica.

Sanfuentes, Olaya (2009), Develando el Nuevo Mundo. Imágenes de un proceso, Chile, Salesianos Impresores S.A.

Sklodowska, Elzbieta (1991), La parodia en la nueva novela hispanoamericana, Amsterdam/Philadelfía, John Benjamins Publishing Company.

Spang, Kurt, Ignacio Arellano y Carlos Mata (eds.) (1998), La novela histórica. Teoría y comentarios, Pamplona, Eunsa.

Todorov, Tzvetan (1998), La Conquista de América. El problema del otro, Barcelona, Siglo XXI. Vargas Llosa, Mario (2002), La verdad de las mentiras, Madrid, Alfaguara.

White, Hayden (2003), El texto histórico como artefacto literario, Barcelona, Paidós. 